\title{
Child's home preparation for school - views of parents. Followed, or unheeded issue in education?
}

\section{Barbora Petrů Puhrová}

\begin{abstract}
The aim of this article is to address a rarely researched area of home preparation in the Czech environment. The area has a significant role in the education process of the child. The article focuses on the shift in the parent's approach to this joint effort of the child and parent and the research description of strategies parents apply to reach the goals set for home preparation. The theoretical bases for the article are the main subjects of home preparation-parents accenting the social context of their family and the specification of the parent's involvement in home preparation in the context of differences in education, sociocultural environment of the parent and the influence of home preparation on the child's success in education. In the qualitative research through interviews with selected parents of lower primary school pupils we show the means of the parent's intervention in home preparation influenced by individual strategies of the parent. The forms and means of involvement in home preparations perceived by parents are presented as particular examples of the research results. The results of interviews with 15 mostly university educated parents show that the aspects of the parent's involvement in home preparations are clearly structured according to the differences in personal and professional conditions and preferences of the parent with the child at lower primary school.
\end{abstract}


Key words: home preparation; homework; family; parent involvement; interview.

\title{
Domácí príprava dítěte na vyučování - pohledy rodičů. Sledovaná nebo opomíjená problematika ve vzdělávání?
}

\begin{abstract}
Abstrakt
Cílem příspěvku je poukázat v českém prostředí na málo zkoumanou problematiku domácí prípravy jakožto významného článku v procesu vzdělávání dítěte. Zaměřujeme se na proměnu př́istupư rodiče $\mathrm{k}$ této společné činnosti rodiče a dítěte a výzkumným popisem strategií rodičů $\mathrm{k}$ dosažení stanovených cílů v domácí prípravě. Teoretická východiska představují hlavní subjekt domácí prípravy - rodiče s akcentem na sociální kontext rodiny a specifikaci zapojení rodiče do domácí prípravy v kontextu rozdílnosti vzdělání, sociokulturního prostředí rodiče a vlivu domácí prípravy na úspěšnost ve vzdělávání dítěte. $V$ rámci kvalitativně orientovaného výzkumného šetření formou interview s vybranými rodiči žáků prvního stupně základní školy poukazujeme na způsoby intervence rodiče $v$ domácí prípravě ovlivněné individuálními strategiemi rodiče. Rodiči vnímané formy a způsoby zapojení do domácí prípravy jsou představovány jako konkrétní příklady výsledků výzkumného šetření. $Z$ výsledků rozhovorů s 15 převážně vysokoškolsky vzdělanými rodiči vyplývá, že aspekty zapojení rodiče do domácí prípravy jsou jednoznačně strukturovány podle rozdílnosti osobních a profesních podmínek i preferencí rodiče s dítětem na primárním stupni vzdělávání.
\end{abstract}

Klíčová slova: domácí príprava; domácí úkoly; rodina, zapojení rodičů; rozhovor.

\section{Introduction}

Upbringing and education are a priority not only in the school educational environment but primarily in the social context of families with children of school age. The particularity of the child's home preparation for school, on all the levels of education from primary to tertiary, is currently an important topic. It is necessary to pay attention to it primarily because home preparation has been researched only rarely in the Czech pedagogical environment. In this study we focused on the area of primary education in which the extent of parents' involvement has the highest intensity mainly in the first and second year of school education (Šulová \& Škrábová, 2012). Compulsory education of the child is a new responsibility for the parent not only in the cooperation of the family and school but also in the involvement in home preparation for school in their home environment. A family and each of its members participate in a system of interactions 
in which transformation of social personality traits occurs and models of behavior of all the members are created (Řezáč, 1998). Primarily, we focus on the parent, his/her individual differences that he/she uses to delimit their own autonomy reflected in their style of upbringing. A specific area reflecting different approaches of the parent are the issues of home preparation for school.

\section{Theoretical Basis}

The area of home preparation and homework has been researched very rarely in the Czech pedagogical environment. The issues related to homework were notably researched by Maňák (1992), Bělohradská, Solfronk \& Urbánek (2001), home preparation of upper primary school pupils was researched by Jursová (2011), and Pospíšilová (2011) compared parents' approaches to home preparation in relation to differences in education of parents. Šulová \& Škrábová (2013), Šulová (2014) focus on parents and starting pupils in home preparation. Smetáčková (2014) provides attitudes of teachers to home preparation. They perceive the education of parents as a certain indicator of success of the child at school. The importance of home preparation for achieving good school results is primarily in the form of repeating and practicing the given curriculum. Currently, there is only a study published by Holte (2016), who discusses the point and effects of homework assigned to lower primary school children. It is the lack of Czech studies and published works covering home preparation that leads us to contribute to the area. Home preparation is characterized as a systematic activity which includes cooperation of the pupil, parent, and teacher (Šulová, 2014). This study adopts Jursová's (2011) approach in which she defines home preparation as all activities, primarily homework, that the pupil does with the aim to "be ready for schooling"-such activities that were not assigned by the teacher directly but that make education easier (the preparation and check of teaching aids, revision, practice, and potential broadening of schoolwork, etc.). The definition of home preparation is thus broadened to include homework that is considered to be a school assignment to be done in a home environment outside school. However, these are considered as activities including home parent-to-child teaching, help with assigned school tasks (projects, preparation of aids, delivery of messages from school, etc.), but also extracurricular activities dedicated to support the child's learning (discussions over books, encyclopedias, the child's hobbies, playing a musical instrument, joint conversation of the parent and child, etc.). Desforges \& Abouchaar (2003, p. 42) claims that the involvement of parents and their support has not only a strong impact on the development of the child during first school years but also creates a positive influence on their school results in adolescence.

The role of the parent in home preparation should be perceived in many various aspects. For one thing, it supports the child's ability to cope with the beginning of school 
education and gradual increase in school's demands related to learning, preparation, and school results. Further, the parent is a role model in behavior and strengthens their child's psychological development and work, social, and enculturational habits. Equally, the parent influences the degree of the child's autoregulation which is reflected in the level of motivation and confidence in their own abilities known as self-efficacya specific capability to manage pressure and solve problems. The cognitive part of autoregulation is related to the child's strategy used to complete an assigned task (Šulová, 2014). There we see the reflection of the parent's approach to the mentioned constituents, i.e., the ability of the parent to motivate and strengthen the child's belief in managing assignments as well as systematically and coherently apply strategies in leading the child through home preparation-autonomously or control-oriented. Many teachers, parents and children accept home preparation for school as a necessary and valuable part of the process of learning (Muhlenbruck, Cooper, Nye, \& Lindsay, 2000). Opponents, primarily those refusing homework, maintain the opinion that the effort, time investment, and stress during home preparation are ineffective and do not yield desired results (Kralovec \& Buell, 2001; Kohn, 2006, 2007).

The findings in the area of the parent's involvement in home preparation compared in foreign researchers, e.g., Carvalho (2001), Warton (2001), Pomerantz, Moorman, \& Litwack (2007), Whitaker \& Hoover-Dempsey (2013), Farrell, \& Danby (2015), argue that:

- parents become involved in home preparation because they think that it helps their child succeed at school;

- parents become involved in home preparation because they care about the future of their child and his/her future education;

- parents consider home preparation to be an emotional, relationship, communicational and, most importantly, time investment into the education of their child, often accompanied by negative behavioral aspects (stress, time pressure, inability or impossibility to help their child);

- parents do not dispute the role of home preparation, they consider it as natural and obligatory arising from their role of the parent.

\subsection{Influence of a Family on Behavior and Learning of Their Child}

The key factor influencing the child in his/her life is the institutional upbringing and education-school (Figueiedo \& Valadao Dias, 2012). We can see the connection between the school and family in home preparation. Grolnick \& Slowiaczek (1994) described three types of involvement in school education of the child. The model describing the predictors of parental involvement in school education of the child is described in the area of behavior (involvement in school activities and home environment, help with homework, questions related to school education, the so-called asking "as at school"), the second area is cognitive-intellectual, and the third is the area of personality. 
The social context of the family is conditioned by the character of personal relations and inner relations in the family as well as by the influence of the wider social environment affecting family culture that is formed by standards, rules and, to a certain extent, it regulates these relationships (Výrost \& Slaměník, 2008). The social status, prestige, and the qualification of parents and primarily the cultural capital of the family can present an important role in this respect (Katrňák, 2006, in Matějů \& Straková, 2010). According to Carlson, Funk \& Nguyen (in Bray \& Stanton, 2013), the process of socialization forms behavior, attitudes, and social skills of the child so that he/she could function as a member of the society. We see the parent as a personality promoting a certain educational style and using strengthening prosocial behavior. As we rely mostly on foreign studies concerning home preparation and homework, we adopt and further use the term parent involvement for parents who are involved in home preparation. Grolnick, Benjet, Kurowski \& Apostoleris (1997) define parent involvement as selflessness, willingness to dedicate their effort and resources in a given area. Parent involvement in the child's education is characterized as the parent's behavior and acting supporting school success of their child. It includes manifestations of parenthood, communication with the school, teaching at home, participation in school events and activities, alternatively volunteering (e.g., School Board). It further includes their involvement in informal educational activities that support the schooling of their child. Respecting socio-economic means of families, we find out that parent involvement of in school and outside school activities differs. The education and socio-economic status of the parent influences their involvement in the education of their child (Spera, 2005, in Bray \& Stanton, 2013; Pomerantz, Moorman \& Litwack, 2007) and is a certain predictor of school success. We adopt the idea that parents in their involvement in home preparation accept school requirements, try to be a part of the school education mechanism, and many of them actively participate in school affairs in many forms and with different intensities (Štech \& Viktorová, 2001). Conditional is "home management" of time, space, but also targeted attention, motivation monitoring, and emotion control of the parent and child that set the character and quality of home preparation $(\mathrm{Xu}, 2013)$. Home preparation provides parents with rapport about the degree of achieved results, information about their child's advance in learning. At the same time, the variability of homework forms motivates and encourages the child's interest in the given subject or curriculum. 


\section{Research}

In the qualitatively oriented research we chose the method of semi-structured interviews to find out:

How do parents get involved in home preparation of their child?

What is their role in home preparation?

What are the specifics that appear during homework in families?

Among fifteen respondents there were thirteen women-mothers and two men-fathers. The respondents live in marriage with two or three children. One woman was a divorced single parent of two under aged children. The majority of the respondents were university educated, only four respondents had high school education with maturita (the Czech high school leaving examination). Another interesting aspect of the research were five parents who were teachers by profession, other parents work in different industries and fields. The profession of teacher was reflected in their experience as they can see it from the other side, from the perspective of school and direct experience with the school environment, the opportunity to compare different children, parents, and peculiarities of school education. The children of our parents were pupils of lower primary school in various years of education, $1^{\text {st }}$ to $5^{\text {th }}$ class. Parents who had more than two children provided answers primarily about the child that participated in lower primary school education because some of the parents already had experience with home preparation with their older child. The majority of the children were in their $3^{\text {rd }}$ to $5^{\text {th }}$ class of lower primary school.

\section{Research Results}

We analyzed the data through opened coding with creating categories that resulted from identically resonating answers of parents in the interviews. Each parent has different approach to the system of home preparation. There are, however, certain common attributes-when the child returns home from school, a short rest, snack or free time follows. The child is then asked to complete assigned homework, prepare aids or study and revise for the next day. Some parents confirmed that children started to complete their homework by themselves, others had to be persuaded or even forced, sometimes they had to be asked repeatedly to be active and complete their homework despite the fact that the parents tried to follow the same procedure. Help is understood as education-teaching the child or supervising in homework completion (Silinskas, Niemi, Lerkkanen \& Nurmi, 2012). The participating parents emphasize the importance of checking and monitoring the child, they describe it as checking of how their child com- 
pleted his/her homework. The parents confirm, in accordance with Mayall (2012), that homework is assigned so that its point is not the child's work itself but its completion is conditioned by monitoring and parental check. The parent $\mathrm{O}$ said how he strategically navigates his son in the organization of environment that can help him manage home preparation: "I can see that he can see a meaning in all that, the tidy desk, the rule of tidy desk, the tidy monitor, and the empty waste bin. Taxonomy, that's how it starts. Then comes the homework, written, but I have not been able to teach M to study continuously, this is what I try, to teach him to study. This is what I want him to accomplish, to revise for every subject, that would satisfy me, that we prepared for school."

This limits the parents in time that is taken away from their other activities in the framework of housework, free time for rest or satisfying own interests. Rage, anger or even yelling become involved in the interaction with the child as the result of tension created by time pressure and often disharmony in the communication with the child. Mother P confirms that: "Because he stays by his own words, that what he says is true and I oppose him and explain that I have more experience. Before anything else, I try to explain in plain language, liken it to something but when it's not successful, yelling comes... and this is how things are and there will no further discussion. There is no time for that."Time, then, is an indicator of pressure and stressing factor in home preparation that influences communication and interaction between the parent and child. Therefore we are in agreement with Cheung \& Pomerantz (2012) that parental motivation of the child contributes to the child's success in learning and the overall management of educational requirements. Simultaneously, conveniently chosen motivation brings the child to gradual autonomy and independence in home preparation (Froiland, 2013).

\section{To be good at School}

Good school results mean good grades for the parents but, on the other hand, the child's satisfaction at school and not fearing school are also important. The [arents talk about the link between the personality of the teacher and their approach to children several times. The approach is reflected in the child's relationship to homework and motivation of the child to learn. School results are connected with immediate reality, are linked to the family's cultural capital, mainly to the parents' interested in personal and educational development of the child, not only about individual qualities and needs of the child. The parent's trust in the child's social rise and attempt at increased school effort and engagement manifested by more intensive home preparation are reflected in the effort to assure the child's success (Kaščák \& Betáková, 2014). Based on our data, it is evident that girls-daughters have, in most cases, lesser or almost no problems with learning at school, home preparation, and the management of the system and rules. 


\section{The Child's Personality-“ a Special Creature"}

Individual qualities, temperament, the child's learning aspirational level but also whether he/she is firstborn, his/her gender and age appear to be important. Mother D supports this argument: "She is a special creature, I say. She is enthusiastic about everything, won't sit for a while, she keeps playing, pretending to be a teacher so you have to play with her." More attention is paid by the parents to the child at the beginning of school education and leads to gradual independence in later years of primary school (learned habits, rituals, and stereotypes). This is supported by a parent of three children: "The middle child, L, is basically an independent, diligent girl, only something, do you understand that, do you want something, yes, mom, train, do you want to know something, exercise or English."

Differences were observed among genders of the children during interviews, the mothers invest more of their time to the children. The mothers argue that it is possible due to their time availability, perhaps they automatically become more involved than the fathers. The fathers spend more time at work and dedicate more of their time to the children during weekends or individualized activities (sports) and help more often with homework in mathematics. Mother R points at the role of the father in home education: "Well, my husband talks a lot with them, he talks to them as if they were his peers, so they stare at him, he finishes explaining, and knows many things, so even before bed time they ask him and he explains. I do not have the patience. He does." Only two fathers agreed to participate in the research sample, their involvement in home preparation is very committed. One of the fathers considers himself to be an extraordinary father in home preparation: "I try to show them unnoticeably that I also go to school, that I have to learn, that I got an A from my exams, as we discussed, that I don't pay only half my attention to it, that I try to do my best. I try to lead them secretly so that they can see me as their role model."This father also criticizes the approach of his wife-mother in preparing their son and takes this task upon himself: "My wife, with all due respect, does not have such authority (laughs), she also tries, she does not have feel for that, yes, she helps him but goes to do something in the kitchen and leaves him alone, then comes back, finds out that he did it wrong and she starts to yell at him... however I can make time for that and sit with him, check his work, as a result it takes more time, you have to check him, and it is ineffective in short."

\section{Problematic Teacher... and the Teacher Again}

In this category, we refer to the teacher's personality in the child's life. It influences the child's attitude to school, learning, and interferes with the family experience-negative experience with a problematic teacher that was reflected in the teacher's approach to the child and raised doubts connected with considering the change of school, interfered with the cooperation with the child, parents, and school is clear from the answer 
mother K provided: "She was such a sad child, she came home, did not smile, we suffered a lot."

Intensive and emotional situations in the family can be caused by negative experience of the child at school and it is consequently reflected in the family environment. Such experience is described by mother P: "Well, it was the first class, it seemed to be OK at the beginning, then came some problems with the teacher and our child, it was a vicious circle. The second class was much worse. When we changed school, in the third class, everything changed rapidly. My son is de facto independent, has good results, learns well. He is livelier, he was even before, the new teacher can lead him, so everything has improved and preparing for school is not so difficult as it used to be in the second class. I was preparing together with my son when he was in the first class but my husband spent much more time with him so I don't know..." Problems at school were reflected in their home environment, the child lacked motivation to fulfill his duties, home preparation became an unpleasant part of the day for the whole family: "I think we were very important for him but the constant school pressure led to such situations that we were looking for his faults, we gave the poor soul a hard time, we pushed him but it didn't have any effect."The mother's response is the reflection of perceived experience of the relationship between school and family. The parent is aware that the teacher does not understand the child and tries to help the child any means possible. It is obvious that the mother cares about the satisfaction of her child at school and strives for a change that was eventually achieved by the joint effort of the family.

\section{Not Always Are Things Easy}

We observed that most parents see a very strong bond between the success of the child and home preparation. It is evident that when the child is successful he/she does not have any problems with learning, home preparation is easier for both the child and parent, mother I: "It is true that E works on them immediately. I do not have any problem, she does it immediately, no matter how much homework she has, mostly cloze tests, she found them herself, she works on them during the summer." The parent's satisfaction is expressed in the statement of mother J: "The kid, if interested, finds it herself, I don't do anything special in this respect." She continues: "... it is probably because she is good at it, really good at it..." On the other hand, if the child faces difficulties during learning as mother $\mathrm{H}$ adds: "... she needs an individual approach, slow approach, and it is true their teachers changed a lot, now she has had the teacher for long time, so it is good, when she comes to me I have to explain everything slowly," then the parent has to invest more attention and energy in order to help their child during home preparation so that the child is more successful and satisfied. Mother $\mathrm{H}$ does not want her daughter to miss classes because every day in the school environment benefits and helps her daughter to manage the curriculum. She does not have "that much" to do in the home environment because she learns at school. This concerns the contact and relationships of children in 
classes as well. As the mother explains in the interview, she is glad that her daughter looks forward to school more than she used to because her teacher understands her difficulties and rather motivates her to learn. The teacher also does not look for mistakes, does not bring them to the child's attention and approaches her individually. Therefore the mother feels more satisfied (maybe even because the teacher taught her older son) and trusts the teacher: "... she needs to catch it at school, the teacher explains differently, and my daughter is among other children."

\section{Conclusion}

As our findings and the study by Moroni, Dumont, Trautwein, Niggli \& Baeriswyl (2015) confirm, parental aspirations are intensely connected to socioeconomic conditions of the family. Similarly, Grolnick, Benjet, Kurowski \& Apostoleris (1997) gather that a strong factor influencing the parent's approach to the child's school education is the family's socioeconomic status. They also confirm that the mothers (without partners) showed lesser involvement. The parents who are more confident of their own ability to help their child are more capable of functioning as parents-teachers.

In this article we demonstrated a specific area of the child's education, i.e., the child's home preparation for education from the perspective of the parent. The home and school environments seem to be necessary for the child's and parent's development of cultural and emotional capital. This cultural-educational process-progressing through the whole life-is connected to both educational realities (Mayall, 2012). We aimed the research, based on interviews with the parents, at direct responses of the parents as main participants in the child's home preparation for education. The results brought, at least partially, the image of the parents and their approaches to home preparation. As far as overlapping of home preparation into future education is concerned, we consider it as a key to pay more attention to this area in future researches. The researches should accent the understanding of the complexity of the family environment system in which home preparation occurs.

\section{References}

Bělohradská, J., Solfronk, J., \& Urbánek, P. (2001). Problematika zatíženosti žáků základní školy domácí prípravou. In: Nové možnosti vzdělávání a pedagogický výzkum. Sborník z IX. celostátní konference ČAPV s mezinárodní účastí. pp. 264-268. Ostrava: Pedagogická fakulta OU.

Carlson, C. (2006). Best models of family therapoy: A vehicle for educators to enhance relationships with families. In Bray, J., \& Stanton, M. (2013). The Wiley-Blackwell Handbook of Family Psychology. West Sussex: Blackwell Publishing Ltd. 
Carvalho, M. (2001). Rethinking Family-School Relations. A Critique of Parental Involvement in Schooling. New york: Routledge.

Desforges, C., \& Abouchaar, A. (2003). The impact of parental involvement, parental support and family education on pupil achievement and adjustment: a literature review. Retriewed from http:// bgfl.org/bgfl/custom/files_uploaded/uploaded_resources/18617/Desforges.pdf

Farrell, A., \& Danby, S. (2015). How does homework "work" for young children? Childrens' accounts of homework in their everyday lives. Retriewed from http://dx.doi.org/10.1080/01425692.2013. 814532

Figueiredo, C., \& Valadão Dias, F. (2012). Families: Influences in Children's Development and Behaviour, From Parents and Teachers' Point of View. Retriewed from https://eric.ed.gov/?id=ED539404

Froiland, J. M. (2013). Parents' Weekly Descriptions of Autonomy Supportive Communicatin: Promoting Children's Motivation to Learn and Positive Emotions. Springer Science+Business Media. DOI 10.1007/s10826-013-9819x

Grolnick, W., Benjet, C., K. C., \& Apostoleris, N. (1997). Predictors of Parental Involvement in Children's Schooling. American Psychological Association, 89(3), 538-548.

Grolnick, W. S., \& Slowiaczek, M. L. (1994). Parents' Involvement in Children's Schooling: A Multidimensional Conceptualization and Motivational Model. Child Development, 65(1), 237-252. DOI: 10.1111/j.1467-8624.1994.tb00747.x

Holte, K. L. (2016). Homework in Primary School: Could It Be Made More Child-Friendly? Studia Paedagogika, 21(4), 13-33.

Cheung, C. S., \& Pomerantz, E. (2012). Why Does Parents'Involvement Enhance Children's Achievement? The Role of Parent-Oriented Motivation. Journal of Educational Psychology, 104(3), 820-832.

Jursová, J. Domácí studijní činnost z pohledu žáků 2. stupně ZŠ. In: Kam směřuje současný pedagogický výzkum? Sborník z XVIII. celostátní konference ČAPV. Liberec: Technická univerzita, 2011.

Kaščák, O., \& Betáková, E. (2014). Vzdelávanie a školovanie v ranom veku v sociálne diferencovanej perspektíve matiek. Retriewed from https://www.sav.sk/journals/uploads/02200957Kascak \%20- \%20zalomena \%200K.pdf

Katrňák, T. (2006). Faktory podmiňující vzdělanostní aspirace žáků devátých tříd základní školy v České republice. In P. Matějů \& J. Straková, et al. Nerovné šance na vzdělání: vzdělanostní nerovnostiv České republice. 2010, Praha: Academia.

Kohn, A. (2006). Abusing Research: The study of Homework and Other Examples. Retriewed from http://www.alfiekohn.org/articles

Kohn, A. (2007). Rethinking homework. Retriewed from http://www.alfiekohn.org/article/rethinking-homework/?print=pdf: \%20www.alfiekohn.org/article/rethinking-homework/?print=pdf

Kralovec, E., \& Buell, J. (2001). End homework now. Beyond Class Time, 58(7), 39-42. Retriewed from http://www.ascd.org/publications/educational-leadership/apr01/vol58/num07/EndHomework-Now.aspx

Maňák, J. (1992). Problém domácích úkolů na základní škole. Brno. Masarykova univerzita.

Mayall, B. (2002). Towards a sociology for Childhood. Glasgow: Open University Press.

Moroni, S., Dumont, H., Trautwein, U., Niggli, A., \& Baeriswyl, F. (2015). The Distinguish Between Quantity and Quality in Research on Parental Involvement: The Example of Parental Help With Homework. Journal of Educational Research, (108), 417-431. DOI: 10.1080/00220671.2014.901283

Muhlenbruck, L., Cooper, H., Nye, B., \& Lindsay, J. (2000). Homework and achievement: Explaining the different strengths of relation at the elementary and secondary school levels. Social Psychology of Education, 3, 295-317.

Pomerantz, E., Moorman, E., \& Litwack, S. (2007). The How, Whom, and Why of Parents' Involvement in Children's Academic Lives: More Is Not Always Better. Retrieved from American Educational Research Association: http://www.jstor.org/stable/4624903 
Pospíšilová, R. (2011). Role rodičů v domácí přípravě do školy. Studia paedagogica, 16(2). DOI: 10.5817/SP2011-2-8

Řezáč, J. (1998). Sociální psychologie. Paido.

Silinskas, G., Niemi, P., Lerkkanen, M. K., \& Nurmi, J. E. (2012). Children's poor academic performance evokes parental homewrk assistance-But does it help? International Journal of Behavioral Development.DOI: 10.1177/065025412456146.

Smetáčková, I. (2014). Domácí příprava v matematice (na pozadí vztahu mezi rodinou a školou). Pedagogika, 64(2), 212-225.

Spera, C. (2005). A review of the relatioinship among parenting practices, parenting styles and adolescent school achievement. In Bray, J., \& Stanton, M. (2013). The Wiley-Blackwell Handbook of Family Psychology. West Sussex: Blackwell Publishing Ltd.

Štech, S., \& Viktorová, I. (2001). Vztahy rodiny a školy - hledání dialogu. In Z. Kolláriková \& B. Pupala (Eds.), Predskolská a elementárna pedagogika. Praha: Portál.

Šulová, L. (2014). Význam domácí prípravy pro začínajícího školáka. Praha: Wolters Kluwer.

Šulová, L., \& Škrábová, M. (2012). Czech study of Home Preparation for School in the First Five Years of School Attendance. Rivista Italiana di Educazione Familiare, 1, 99-113. Retriewed from http://www.fupress.com/rief

Výrost, J., \& Slaměník, I. (2008). Sociální psychologie. Praha: Grada.

Warton, P. (2001). The forgotten voices in homework: views of students. Educational Psychologist, 36(3), 155-165.

Whitaker, M., \& Hoover-Dempsey, K. (2013). School Inflences on Parents' Role Beliefs. The Elementary School Journal 114(1), 73-99. DOI: 10.1086/671061

Xu, J. (2013). Why Do Students Have Difficulties Completing Homework? The Need for Homework Management. Journal of Education and Training Studies, 1(1). Retriewed from http://dx.doi. org/10.11114/jets.v1i1.78

\section{Contact:}

Mgr. Barbora Petrů Puhrová

Department of School Education, Faculty of Humanities, Tomas Bata University in Zlín

Štefánikova 5670, 76001 Zlín, Czech Republic

E-mail: petru_puhrova@utb.cz

Mgr. Barbora Petrů Puhrová graduated the Faculty of Education, University of Ostrava, study programme Teacher Training for Primary School (specialization Drama Education). During her thirteen years teaching practice, she worked as a teacher and head of pre-primary and primary schools. She is currently studying the Doctoral Degree Program of Pedagogy at Tomas Bata University in Zlín, where she is working as a lecturer at the Department of School Pedagogy. The main areas of her interest include the issue of school management, cooperation between kindergarten and primary school. Her research is mainly focused on child's homework at the primary school, especially from the family environment perspective. 